\title{
Ageing in Inner Cities
}

\section{The Residential Dilemmas of the Baby Boomer Generation}

\author{
BY CATHERINE BONVALET ${ }^{1} \mathcal{E}$ JIM OGG $^{2}$
}

\begin{abstract}
Although residential mobility decreases with age, rates rise around the age of retirement, especially for people living in cities. The post-war birth cohort of 1945-1954 differs in many respects from previous generations, and these differences are currently influencing residential choices made around the age of retirement. Using data from 60 semi-structured interviews in four areas of London and Paris that have undergone gentrification, this paper examines the residential trajectories and choices facing members of the 1945-1954 birth cohort. The analysis reveals three types of residential trajectories - 'pioneers of gentrification', 'city movers' and 'local inhabitants'. These trajectories are intertwined with contextual factors such as life course events, family situation, housing market conditions, and the institutions of Britain and France. The analysis shows that pioneers of gentrification have more opportunities for choice in future residential locations, and are tending to adopt complex residential patterns that often involve a combination of extended stays throughout the year in different locations. Whilst they still favour a city life, their current

1 Catherine Bonvalet, Institut National d'Etudes Démographiques, Paris, France.

2 Jim Ogg, The Young Foundation, London, UK.
\end{abstract}


neighbourhood location is not a priority in any future residential choice. City movers have lived in diverse locations over the life course and although they too express a continued preference for the city, ties to the local neighbourhood remain relatively weak. Among the 'local' inhabitants, differentiation from the gentrifers is strong, and attachment to the local neighbourhood depends upon the context of the urban setting. The British and French contexts of housing policy and markets play an important role in determining residential mobility. Collectively, the analysis shows that there is little 'stability' in the choices for current cohorts of people in cities approaching retirement, with few interviewees having formed a definitive plan for a future residential location.

Keywords: Baby boom generation, residential mobility, residential choice, gentrification, Britain and France

\section{Introduction}

Members of the baby boomer generation (defined here as the birth cohort of 1945-1954) that live in inner cities generally fall into two groups: 'newcomers' - those who made the move to the city in early adulthood or later and have since stayed, and 'local' inhabitants who have remained in, or near the neighbourhood where they grew up. ${ }^{1}$ Among the former, some individuals were part of the vanguard of the gentrification process

1 It is difficult to obtain statistically representative information on residential histories. For the UK, several surveys (for example the English Housing Survey, the English Longitudinal Survey of Ageing, and the Census) record information about recent changes of address and the number of years lived at a particular address. However, information on the length of time spent in a particular neighbourhood and residential trajectories made within neighbourhoods is mostly absent. Even when such information does exist, it is usually to be found in modules (for example the British Attitudes Survey, 2004) which do not have enough cases once the analysis descends to particular localities and specific age groups. The same methodological problem applies for France. Throughout the paper we use the terms 'newcomers' and 'locals' to refer respectively to people who moved to London or Paris after growing up elsewhere and people who grew up in London or Paris. 
that was common to certain areas of large cities in the 1970s and 1980s, notably in London and Paris. Having moved to previously working class areas, many of these mostly middle class young professionals gradually became embedded in networks created by the schooling of their children and other activities. As they moved through the life course, some left the city whilst at the peak of their working careers, but others stayed, often setting down firm roots and developing social capital within their neighbourhoods (Butler \& Robson 2001). As for the 'local' inhabitants of the baby boomer generation, many are from traditional working class communities and unlike the 'newcomers' they are less likely to be homeowners. They also tend to have been less residentially mobile than newcomers, and by definition are more likely to have lived a longer time within the neighbourhood. ${ }^{2}$ Nevertheless, as for newcomers, family formations and dissolution and employment histories have contributed towards determining particular residential trajectories throughout the life course.

Today as both the 'newcomers' and the 'locals' approach retirement and with the schooling of their children for the most part completed, many are faced with a new set of residential choices. These choices are motivated by diverse factors, including financial resources (future anticipated income in retirement and housing equity), family situations, perceptions of the local neighbourhood, and importantly, the prospect of growing old in the city. Although residential mobility tends to decrease with age, cities tend to have higher rates of out-migration among adults of retirement age than the general population. The baby boomer generation is also associated with new forms or 'cultures' of mobility (Urry 2001) which can involve complex residential strategies. Important questions are therefore raised concerning the intentions of the baby boomer generation living in inner cities. Does the city still hold all the positive features that made it so attractive to the 'newcomers'? How do the 'local' inhabitants

2 Data from the 2004 British Social Attitudes Survey show that only about one in ten members of the 1945-1954 birth cohort have lived in the same neighbourhood all their lives. These rates were respectively $14 \%$ among respondents from lower class groups compared to $7 \%$ among higher-class groups (authors' analysis). 
perceive the transformations within their neighbourhood?

These questions are examined through the narratives of 60 Londoners and Parisians born between 1945 and 1954 who were living in inner city neighbourhoods in 2006. Although London and Paris share many of the characteristics associated with large cities, there are important differences. The centre of the Paris conurbation, 'la ville de Paris', is an area of only $87 \mathrm{~km}^{2}$ compared to the $321 \mathrm{~km}^{2}$ of Inner London (Pinçon \& PinçonCharlot 2004). At the same time, the population of Paris is much more dense (22,500 inhabitants per square kilometre in Paris compared to 9,300 in Inner London) and urban space is at a premium. Unlike London, Paris has a housing stock that comprises almost universally apartment blocks. The concentration of shops and local services is greater in Paris than in London, and the history of in-migration, as well as policies concerning social housing and the local housing market, differ strongly between the two cities. These disparities influence residential strategies and a comparison of inner cities that differ substantially allows hypotheses and tentative conclusions to be drawn concerning ageing in inner cities.

\section{Migrants to the City}

Cities have always been associated with a high in-migration of young people (Rothenberg Pack 1973). For much of the twentieth century, as rural communities declined and urbanisation spread, young adults moved to the city primarily to seek work. But during the 1960s they also came to escape the confines of provincial life. These new arrivals were part of the baby boom of the immediate post-war period, young adults with ideals and values different from their parents. Many rejected the lifestyles associated with rural or even suburban communities and they eagerly sought new experiences offered by the city. For some, the city was the perfect setting to promote the ideals of the 1960s counter-culture.

Arriving in London and Paris during the 1960s and 1970s, young people on the whole experienced less difficulty in finding accommodation when compared to previous generations or young people today. Cheap, mostly run-down bed-sits were available to rent. In London, some of these mainly middle-class young people, entered the squatting scene, either ideologically motivated or as a temporary staging post on 
the route to finding more permanent accommodation (Dench et al. 2006). In Paris, where squatting was much less common than in London, the 'chambre de bonne', a small studio flat at the top of $19^{\text {th }}$ century Hausmann apartment blocks, was a common first time accommodation for young arrivals to the city. London in particular offered a range of professional opportunities to which young middle class individuals of the baby boomer generation could aspire. A strong local government sector coupled with emerging voluntary groups and independent charities attracted teachers, social and community workers, and other public sector workers. The traditional middle class occupations of lawyers and professions associated with the arts were also expanding, and the young baby boomers new to the city began to enter them in numbers. In France, the influx of the baby boomer generation to Paris during the 1960s and 1970s still had many features common with early patterns of in-migration to cities, since France at this time retained a fast declining rural base from which young people were more or less compelled to leave to find work (Bonvalet \& Merlin 1988; Cribier 1988). Nevertheless, the events surrounding May 1968 and the zeitgeist of the 1960s also attracted young French people to the city in quest of new experiences.

Having arrived and lived out their student years, most of these young baby boomers embarked on careers and began to form families. Some remained in rented accommodation, in London mainly through housing associations or the local council, in Paris mostly in the private sector. Others began to buy property, particularly in run-down areas where house prices were affordable. These young, predominately middle class individuals, were among the vanguard of the accelerating process of gentrification, first identified in the 1960s (Glass 1964). Gentrification has been defined as "a process involving a change in the population of landusers such that the new users are of a higher socio-economic status than the previous users, together with an associated change in the built environment through a reinvestment in fixed capital." (Clark 2005). This process has been the subject of much research, debate and recently critical appraisal (Ley 1996; Smith 1996; Butler 1997; Hamnett 2003). In its original formulation, gentrification signified changes brought about by deindustrialization whereby the new middle-class incomers displaced the working class inhabitants. However, these changes went further than simple 
population flows. They represented fundamental transformations to the class dimensions of localities and neighbourhoods.

Gentrification was thus seen as important theoretical concept to explain social mobility. More recently, gentrification has taken on other meanings, in particular the relationship between people and place. As Butler (2006) notes 'the great strength of gentrification research has been its ability to throw light on how changes in the external economy have affected the relations between people and the places that they live in'. Areas of inner cities that have been gentrified are now recognised to contain subtle differences relating to the 'differential deployment of cultural, social and economic capital by their middle-class residents' (Butler \& Robson 2001). Areas where the process of gentrification took place on a large scale include parts of Hackney, Islington, Tower Hamlets and Lewisham in London and several areas (arrondissements) towards the east of Paris as well as the immediate suburbs towards the south. Although the timing of the process of gentrification is difficult to measure, in Paris it appears to have taken place at a slightly later date than in London around the 1980s - and in more confined geographical spaces (Pinçon \& Pinçon-Charlot 2004). ${ }^{3}$

During the 1980s, some of the baby boomers who had migrated to London and Paris several years previously became rooted in their localities through contact with other, predominately middle class parents sharing similar backgrounds. Links to the local community were forged, though as some commentators have suggested, the incomers associated with gentrification often created 'communities in the mind' which were essentially middle class perceptions of inner city life (Butler 1997). Unlike previous generations of middle class incomers to cities who moved to the suburbs as their careers developed, some of the baby boomer generation preferred to stay in the inner city, although a move to the suburbs remained an important trend. In Paris, a survey of the 1930-1950 cohort undertaken in 2000 found that being single, separated, and middle class -

3 Pinçon and Pinçon-Charlot, using data on changes in the social class composition of Paris between 1962 and 1999, have shown how increased rates of higher social class groups in the capital have mostly occurred in previously working class areas (quartiers populaires). 
characteristics frequently associated with the baby boom generation were associated with having moved to the city from the provinces when a young adult (Bonvalet et al. 2007). In London, as Savage et al. (2005) have argued, many of those who did not move away and chose to stay 'indefinitely' in these areas gradually built up a sense of 'elective belonging' to their localities and a developing community attachment.

As they approach retirement age, some of the original incentives that drove the newcomers to the city in their youth may no longer be present or as compelling. Middle age baby boomers are not (or less so) tied to the area by professional or career concerns. For most, the schooling of children is over, although mid-lifers have not been untouched by the trend of children delaying the age at which they permanently leave the parental home. Some have divorced or separated, the rise in divorce being a phenomena strongly associated with this age cohort, and families have become geographically dispersed. The areas have also changed in many ways. Second or third waves of 'super-gentrification', led by high income city workers have occurred in many places and pockets of white working class areas have been replaced by new generations of immigrants from abroad. These trends are part of a larger process of globalization which is generating new forms of mobility in later life characterised by 'an expanding mix of spaces, communities and lifestyle settings' (Phillipson 2007). Conscious of these transformations, many middle-age baby boomers are facing new dilemmas and contemplating new horizons as they approach retirement. Does the city still offer the opportunities that it had some thirty years previously and importantly, is it an appropriate environment for old age?

\section{Local Inhabitants}

In contrast to the newcomers, members of the baby boom generation who grew up in or near the neighbourhood where they currently live have a longer perspective from which to gauge the changes to their local environment. In gentrified areas, these local inhabitants are mainly from working class backgrounds. Several British studies have commented on the disenchantment that older members of these working class communities feel about the social transformation of their neighbourhoods (Phil- 
lipson et al.. 2001; Scharf et al. 2001; Dench et al. 2006). One striking feature of the expression of this discontentment is the reconstruction of a 'golden era' when crime was less rife, family ties stronger, and a sense of civic pride in the neighbourhood existed which bound together the community. Local members of a neighbourhood, perhaps especially as they age, tend to look back with affection on bygone times and happier days. Unlike the newcomers whose 'communities in the mind' relate to their everyday experience, those of the 'locals' tend to be rooted in the past. Additionally, as Dench et al. (2006) have shown in a recent study of an inner-city district in London, difficulties in achieving multi-cultural ideals have been acute in areas of high immigration with traditional working class communities. These difficulties are often expressed by people who have lived most of their lives in the same neighbourhood.

As young adults, the city did not necessarily hold the same allure for the 'local' inhabitants as it did for the 'newcomers'. This was, of course, mainly a question of social class. But perceptions of the city were also determined by childhood experience and reference points. The stark contrast of the city to the province could not exist for the 'locals' and therefore the exoticism which is so much a part of the newcomers' experience was mainly absent. As far as housing was concerned, many of these 'lo-

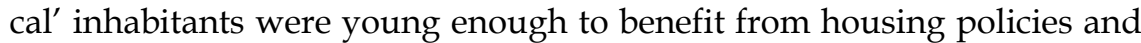
practices that promoted the transfer of rented property between family members. Council flats in London and housing belonging to the town hall of Paris were 'inherited' by younger family members, and today some of the baby boom generation remain in these local authority flats. In Paris, the 1948 housing legislation which facilitated the intergenerational transfer of rental property has 'enabled populations which would otherwise, for reasons of cost, be forced to move out to the suburbs, to continue living in the city centre' (Loiseau \& Bonvalet 2005). Others became property owners and climbed the housing ladder in the same way as the newcomers, though perhaps at a slightly slower pace.

As the 'local inhabitants' approach retirement age, they too are facing dilemmas about where to live out their old age. For many, the life course determinants are the same as for the migrant baby boomers to London. And although some 'locals' do not have the resources that facilitate and widen the scope of residential choices, others have experienced 
the property boom at first hand. For some, traditional patterns of retirement migration, such as Essex for East Londoners, Kent for south Londoners, and the departments around the Paris region for Parisians, remain desired locations. For others, and especially in the British context, retirement migration abroad has been one solution adopted by working class retirees, with one objective being to regain a sense of lost of community.

\section{Retirement Migration}

The residential choices of ageing baby boomers in inner cities needs to be set in the context of the considerable literature on retirement migration. Longino (2001) has suggested three conceptual models to understand retirement migration. The first is the 'life course model', where the focus of study is the mechanisms associated with life events triggering major changes. Residential mobility and changing housing needs are seen as consequences of major life events such as marriage, children reaching school age, divorce, a change in job, and eventually, retirement. In this model, the choice of destination is contingent on the life event and often planned long in advance, as for example a return to one's place of birth or a permanent move to a second home. The second model centres on 'migration decisions', where the decision to move is made prior to the choice of destination. For retirement migration, examples include the decision to move to a warmer climate or to escape what is perceived to be a deterioration in the local area. In contrast to the life course model, one of the main motives behind this residential choice can be discontentment with the local area. A third model is the 'housing disequilibrium model', whereby 'economic incentives due to housing assets may be assessed within the context of the migration decision model'. Residential mobility in this model is fuelled by changes in house price markets, which in recent years has mostly meant using the equity in a current home to move to a different area where housing is cheaper. These three models serve as heuristic devices to understand retirement migration and often elements of all three are present in residential choices.

Empirically, although previous studies have shown that the passage to retirement is associated with a house move (Wiseman 1980; Warnes 
1992; Ermisch \& Jenkins 1999; Tatsiramos 2006), residential mobility is known to decrease significantly with age. In France, the 2002 housing survey recorded only a slight upward trend in mobility around the age of retirement. Between 1990 and 1999, only one in five persons aged 60 and above moved home compared to approximately half of the population under sixty (Christel 2006). However, this mobility was much more common in the greater Paris region, where older households tended to move larger distances compared to retirees in other regions (Christel 2006). For Britain, using data from the 2001 census, Champion (2005) has shown that London remains the foremost city in the UK for outward migration, and moreover that 45-59 year olds are, after the 30-44 year old age group, the age group most likely to be associated with this outward migration.

It is still too early to evaluate current and future patterns of retirement migration in cities, but preliminary evidence suggests that outmigration patterns may be slowing. French research for example, has shown that the baby boomer generation approaching retirement is much more reluctant to make a permanent move from the city to the village previously a strong feature of retirement migration in France (Cribier 1988) - than previous generations (Bonvalet 2007). Many members of the baby boomer generation enjoy the qualities of both city and rural life, and where possible divide their time between the two locations. Frequent mobility between the city and country in retirement may therefore be a future trend. Louchart (2007) has shown that for the Paris conurbation, among the most recent retirees, the trend of moving away towards destinations is continuing for the first cohorts of the baby boomer generation. A move away from inner cities on retirement remains common, as can be seen in figures from home sales in the Paris region in 2003 - more than one in five sales (21.5 per cent) were made by retired households, who in turn represented only 6 per cent of purchases (Bonvalet et al. 2007).

In London, Butler and Robson (2003) have suggested that some of the London gentrifiers they interviewed in the 1990s whilst at the peak of their careers, still planned to move away from London to rural settings on or near their retirement, but as previously discussed, many in-comers have forged identities and a sense of belonging in their localities which may act as strong disincentives to moving home. Data from the English Longitudinal Survey of Ageing show a relatively high rate of second 
home ownership among the 1945-54 birth cohort (15\%) and although no data are available for the middle class gentrifiers living in the inner city, this figure is likely to be higher. It is possible that that 'circular' patterns of residential mobility between a main home and a second home are common (Lelièvre \& Bonvalet 1994; Bonnin \& Villanova 1999; Gotman 1989; Warnes 2007). As Urry (2001) has noted, the contemporary middle classes are driven by a 'compulsion to mobility' and this trend towards a 'mobile culture' may be particularly present around retirement. Many of the newcomers may thus have multiple attachments to different areas, creating dilemmas about where to pass their retirement and what type of environment is suitable for growing old.

These questions about the residential choices of mid-lifers are examined in detail through empirical data of mid-lifers in the 1945-1954 birth cohort, the first of the baby boomer generation that is now approaching retirement. Using narratives that relate to their neighbourhood and residential decisions for the future, we explore how members of this generation construct images of their local environment and articulate future residential options.

\section{Data and Method}

The data comprise the results of a series of $60 \mathrm{semi}$-structured interviews with men and women born between 1945 and 1954 undertaken in London and Paris between April and September, 2006. ${ }^{4}$ Four localities were chosen to reflect inner city areas that had undergone (and are still undergoing) major transformations, among which included gentrification. In Paris, the sample selection was made by telephone, whereas in London it was a mixture of street recruitment and snowballing. Both of these methods contain elements of bias which need to be taken into account when interpreting the results. The major difficulty encountered was that in the early stages of the sample selection, a bias towards unemployed or economically inactive respondents occurred, which we subsequently had to

4 The research was funded by the PUCA (plan urbanisme construction architecture) of the French Ministry of Housing and Town Planning and supported by the Young Foundation, London. 
address. In addition, the snowball method of sampling in London may have introduced unadjusted elements of bias. Notwithstanding these difficulties, the final sample was stratified to include an equal number of men and women, and household tenure representative of the local areas. The interview schedule contained questions retracing the residential mobility of respondents since childhood, family formation, attitudes to the local environment and retirement mobility decisions. In London, 17 of the 30 interviewees arrived as young adults, and in Paris the figure was 12. The areas represented different types of gentrification, reflecting the degree to which the middle classes had embedded themselves in the local neighbourhood.

All of the 60 interviews were transcribed and analysed using two different software packages (Alceste and Nvivo). The conceptual framework for the analysis is based on previous work undertaken on the residential trajectories of Parisians in 1992 and 2000 (Bonvalet et al. 2007). This approach takes as axiomatic the proposition that people and places are inextricably linked in networks that evolve over time. Residential choices are not simply contingent on current conditions such as the housing market or other financial considerations, important though these are, but also on the convergence of many antecedent factors. Among these factors, extended family life as witnessed by the existence of multiple households dispersed in geographical space, is crucial to understanding the residential trajectories, both past and potential, of individuals and households. Understanding the past gives important clues about future residential choices. Respondents were therefore asked to detail sequences of events (in this case residential histories) and the motives for their behaviour. The chain of residential moves since childhood was then linked to wider social network configurations, and through this process a series of residential trajectories was constructed into which respondents were grouped.

A key feature of the method is the comparison between the English and French contexts of ageing in inner cities, and the different types of gentrification. As outlined above, all of the areas selected have experienced major social transformations and gentrification. Both capitals have experienced a high level of housing inflation and in 2006 property prices in these areas were among the highest in each respective country. At the same time, there are many differences. Space in Paris is at a premium, 
with most of the housing stock existing as apartment blocks or flats. Historical antecedents, such as the 1948 French legislation which facilitated the transfer of rented property between family members and guarantees artificially low rents, have created the conditions for 'atypical' residential trajectories. Differences in credit facilities and attitudes to borrowing result in divergent contexts of the housing economy. This comparative dimension and its impact on the residential trajectories of the baby boom generation are discussed following a presentation of the findings.

\section{Analysis}

The analysis of the interviews confirmed the general pattern of two groups of inhabitants - newcomers and local inhabitants. However, we found a further sub-division of the newcomers category was necessary to distinguish those residents whose housing strategies resembled closely the process of gentrification from other newcomers. Although this distinction followed closely different social class divisions, the timing of arrival in London and Paris between these two groups of newcomers was also different. We have used the label 'pioneers of gentrification' to categorise the mainly middle class members of the baby boom generation who moved to the city in their youth and bought property when in their thirties. These residents had lived at their current address on average longer than other newcomers. They had benefited from the successive London property booms and their residential choices had been carefully designed to capitalise on the benefits of urban regeneration. They had reached the 'peak' of their housing career, in so far as their housing met most of their needs in terms of space and quality. These pioneers of gentrification in London often lived in semi-detached four-bedroom homes with gardens.

The second type was the 'city movers'. This includes men and women who had also migrated to Paris or London, although not necessarily in their youth. Although city movers can be considered to be part of a larger process of gentrification, their role in this process was more blurred than the pioneers and they cannot be seen as being key actors. The analysis of their residential strategies did not reveal the classic pattern of gentrification - the infiltration of those parts of the inner city that 
had been abandoned and where there was great potential for renovation and home improvements. Many of these residents expressed their feeling of being 'caught up' in the gentrification process rather than being the cause. The city movers had more constraints upon their residential choices than the pioneers. This was partly due to social class and lower incomes, but we also found that the city movers often came to the area following a separation or divorce. In Paris, many rented their accommodation, either in the private or social sector.

The third trajectory concerns the 'local inhabitants' - individuals who had lived all their lives in the inner city, mostly in the same local area. In contrast to the newcomers, many had close family members living nearby. This group of residents had witnessed the enormous changes to their areas at first-hand. Most had benefited and spoke positively about the general improvements to the local environment. However, these residents were less positive about perceived changes in the composition of the local population, along both social class and ethnic dimensions.

Using this tripartite classification of the baby boomer generation of residents in Paris and London, we now turn to present case studies that illustrate these trends and the dilemmas facing the ageing residents of inner cities.

\section{Pioneers of Gentrification}

'Pioneers' of gentrification concern those middle class individuals who moved into the inner city at the height of the gentrification process during the early 1980s or earlier. Our London example is Cathy, born in Manchester to middle class parents in 1950 (56 at the time of interview). At 19, she left to study at one of the new universities because

this was the university of its time..., people were breaking out of the confines of various sorts of behaviour. So going to this university was an expression for me of getting away from a confined sort of environment.

Following university, Cathy travelled for a few months and after a couple of years of moving around England, during which time she studied to become a social worker, moved to London. Cathy had no difficulty find- 
ing a squat, where she stayed for two years. Towards the end of her time in the squat, life 'became unbearable' and she managed to get a council flat and subsequently a housing association flat. By now a parent, she bought her first small house in the 1980s in a gentrifying area of north London. From there, she moved quickly up the housing ladder, moving in 1986 a little further north in the borough. The rationale for this move was a classic feature of gentrification - to acquire larger and cheaper housing in a more run-down part of the borough but within easy access of the 'hub' and appropriate schooling for her children. In the mid 1990s she moved into her current home with her partner and two children, a large four bedroom house situated within a stone's throw of the numerous restaurants, cinemas, and antique shops that form the heart of this gentrified area of London. In 2006 the property had a market value of around 1 million euros.

For Cathy, the city had lost none of its original appeal:

I really like the diversity of it. I like this very mixed feel that the area has.

In the prime of her professional career, Cathy took regular advantage of the facilities that her local neighbourhood, and perhaps more importantly, central London had to offer. She was a regular cinema goer, sometimes going alone at other times with a friend. But social capital was mainly confined to a circle of friends and colleagues and her two daughters, with no involvement in the local neighbourhood. Cathy was not completely settled in her current home, having a few years earlier separated from her partner and finding her current house too large for herself and her daughter, who was increasingly spending time away from home. Cathy did not have a second home, but this does not mean that she was immobile:

I travel a lot. If I've got to speak at a conference or something of that sort, I might add on a couple of days, so I have quite a lot of frequent trips in Europe. And last year I went to America three times because my daughter was at an American college. And also my family has got a place in Thailand, so I want to Thailand last year on a long trip.

Cathy still had an 'interest-only' mortgage on her house which she 
believed would be difficult to keep up when she retires. ${ }^{5}$ So she envisaged moving home and downsizing, using a conventional way of releasing capital to provide income in retirement:

I don't think I'd be interested in an equity release scheme because I've heard that they are not great value. ${ }^{6}$ And you don't know where they are going, because if you live a long time, and all that. If you are sitting on a heap of equity and if you can discharge your mortgage and you have still got more than you need, well then, that seems to me reasonable if you buy a smaller place, and then whatever is left over, you invest to keep you going.

But the choice of destination was uncertain. Although moving outside London was possible, because

it's better value for money and in terms of things I now like doing, things like walking and less of the action.

Cathy was clear that she

...wouldn't ever want to be too far from London because that's very important.

The example of Cathy was not atypical of other pioneers of gentrification in London. With children no longer at school in the local area and unlikely to settle in the local neighbourhood because of high accommodation costs, attachments to the local area were not strong. City life, in particular cultural diversity and easy access to a wide-range of facilities, remained important features in any future residential choices, but these cosmopolitan attributes outweighed any advantages of the immediate

5 A mortgage is 'interest only' if the scheduled monthly repayment consists of interest only and not the repayment of the principal loan. Because the principal loan is not repaid until the sale of the house, the borrower relies on the market appreciation of the value of the home (equity) for repayment. In gentrified areas where house prices rise quicker than the average, this type of mortgage has become more common in recent years.

6 Equity release schemes are financial products offered to older people (generally $60+$ ). The schemes consist of selling a home (or part of it) to a plan provider in return for a cash sum or monthly income. 
neighbourhoods. The inflated house prices and the housing equity which had been accumulated opened up many potential avenues of future residential locations, and downsizing by moving out of the neighbourhood was a commonly cited strategy. However, on the whole, staying in London, although not necessarily in the neighbourhood, was a desired future residential choice. Even in the few cases where pioneers of gentrification were planning on leaving London 'for good', this decision was recognised as 'a leap in the dark' which may have to be reversed in the future.

In Paris, the pioneer of gentrification is represented by Brigitte, born in 1951 (55 at the time of interview) in a provincial town in northern France to lower middle class parents. Brigitte trained in northern France in the late 1960s as a mid-wife, and after meeting her future husband, both decided to move to the capital in 1973 to escape from a region where they felt 'hemmed in' and where 'everyone knew each other'. The couple managed to find a small, privately rented flat relatively easily in the $14^{\text {th }}$ arrondissement, but mindful of the future, they decided to buy in 1979 . With their budget, the $14^{\text {th }}$ arrondissement was too expensive, so they moved slightly to the east. Here they found a three bedroom flat in what was then a predominately working class area that was quickly becoming gentrified - 'it was the flat that attracted us, not the neighbourhood'. Like many of their contemporaries, the couple took out a 15 year mortgage. Four years later, in 1983, after Brigitte's husband's business began to take off, the couple bought a second home in northern France, close to their family members, where they often stayed at week-ends. In 1992, after having paid off their first mortgage, the couple borrowed again and bought a studio flat in the block where they currently live, a strategy with investment motives as well as providing free accommodation for their teenage son. More recently, they also acquired a time-share in a ski-resort region of the Alps. Here is how Brigitte explained the changes to her area:

Many of the apartment blocks around here have been renovated. Some of the very small streets used to be practically no-go areas, but all that has since changed. I think that that things have definitely got better, and that as a result, the area has become fashionable. 
Brigitte had two sons, one still practically at home, the other renting a flat a few kilometres away and planning to buy a property in Paris. With the likelihood that her other son would also stay in Paris, and contrary to the pattern of London pioneers of gentrification, Brigitte had no intention of moving home:

I like the area where I live very much, I don't see reasons why I should move away. Our flat is neither too big nor too small. Should we automatically change home for something smaller just because the children have left home? I don't think so.

Although Brigitte had no formal links with neighbourhood voluntary associations, club membership or other activities, the diversity of the local neighbourhood and the accessibility of facilities still retained a lot of attraction. Moreover, Brigitte found that one could achieve the right balance between anonymity and neighbourliness, a balance that was difficulty to find in many other settings. Nevertheless, Brigitte and her husband had a retirement project of buying a second home in Morocco, following a growing trend of French retirees:

I like Morocco a lot. My husband says that we ought to buy a second home in the north of Spain if we want to see the children more often. But they could still come by plane and property is a lot cheaper in Morocco than Spain.

These pioneers of gentrification, as the cases of Cathy and Brigitte clearly show, still felt an attachment to the city, although this attachment manifested itself in different ways according to the context, London or Paris. In London, Cathy was not the only pioneer of gentrification that expressed a desire to remain in the city whilst not ruling out a change of neighbourhood. Where one of the principle motives for remaining in the area - the schooling of the children - was no longer present, horizons broadened and the attractions of the immediate neighbourhood became somewhat diluted. A further factor precipitating a potential home move for the London gentrifiers was the prospect of a significant drop in income during the transition to retirement. Large houses acquired in gentrified areas require upkeep and this was a cause of anxiety to several of the pioneers of gentrification. In Paris, pioneers appeared to have remained more attached to their local neighbourhood, or at least seeing no 
obvious advantages from moving around within the city. The housing disequilibrium context of making residential choices was much less an issue than for London pioneers of gentrification, where housing wealth was a prime motivator for making decisions about residential location.

Thus the pioneers of gentrification, whether in London or Paris, retained a sense of attachment to city lifestyles and many envisaged growing old in the city. For Londoners, the possibility of future moves in the city and downsizing was a more recurrent theme than for the Parisians. The probability of a future move seemed greater for the London pioneers, and the motives behind residential choices more complex, relating to the housing market and future income from pensions. In Paris, the pioneers appeared to operate more within a life course model of retirement decisions, often set in the context of practices linked to French institutional and cultural life - such as the transmission of second homes within the family, secure pensions, less housing equity than in London, and more heterogeneity in the type of housing available. However, in both cities, the pioneers of gentrification had been transformed into pioneers of a mobile culture. In both cases, residential strategies were complex, with individuals and couples generally 'on the move', planning over the year to be in different locations according to work and family commitments and aspiring to maintain this mobile lifestyle through into old age. Residential choices involving second homes, time-shares and for some, extended periods of time spent away from the inner city were conceived and articulated in geographical spaces that were intertwined with family considerations.

\section{City Movers}

'City movers' were individuals who were not prime gentrifiers or who had been at their current address for shorter periods than the pioneers of gentrification. They tended to see themselves as passive actors in the process of social transformation that was characteristic of their neighbourhood, especially concerning gentrification. In their narratives, it was the area that had undergone the process of gentrification and they had been witness to this change, not actors within it. Perceptions of the area, whilst still positive, were mainly framed around physical improve- 
ments in housing, buildings and amenities, whereas disapproval was expressed for the overt signs of gentrification such as trendy cafés and restaurants. Our Paris example is Jean-François, born in southern France to lower middle class parents in 1947. Although Jean-François moved to Paris as a young adult, he had only been in his current neighbourhood since 1997. Together with his second wife, Jean-François had made several moves during his adult life within Paris and the suburbs and his residential history displayed features particular to the Paris context - a move from the inner city to the suburbs and back again to the inner city. In 2006, the couple were renting their two bedroom flat which had been found through Jean Francois' wife's employer under a scheme which keeps rents below the market value. Nevertheless, they were owners of a small flat in the Paris suburbs, which they had bought for their son and kept on as an investment once he married and left, renting it to students.

Jean-François liked the area where he lived, but showed no great attachment to it:

this is a very mixed area, but I must admit that I don't go out and make much use of it, because I don't have the time and to tell the truth, I don't know it very well. But the area has improved a lot, even in the ten years since we have been here.

Jean-François preferred the ambiance of a neighbouring arrondissement where he had lived in the 1980s. But his real plan was to live six months in Paris and six months of the year elsewhere in France, although he had no firm destination in mind. For Jean-François, it was inconceivable that he should definitely leave the city, because

I have always lived in the city, and after three weeks away, I miss the noise of the streets, the métro, the buses and all the humdrum of city life.

Another important factor in Jean-François' future residential choice was being close to his grandchildren, who also lived in Paris.

Jean-François' residential trajectory was typical of many Parisians for whom the proximity of family members and the historical context of housing policy played a large role in determining future residential strategies. Jean-François and his wife had no firm plans to move, knowing that they could obtain little in the way of similar accommodation for 
the same rent and that it was not possible on their budget and at this stage in the life course to buy property in their current neighbourhood. The security of tenure coupled with a rent lower than the market value of the property were important factors for any future residential choices. The local neighbourhood was a secondary factor, with positive attributes being expressed in simple terms such as its good link with the metro and the cleanliness of the apartment block. Social capital consisted predominately of immediate family living close by and this was a further important motive influencing any future residential choice.

In London, Chris is an example of a city dweller with similarities to Jean-François in so far as his attachment to the area was relatively weak. Chris was born in Yorkshire in 1948. He moved to London in 1969, originally north of the river. In 1994, he and his partner decided to buy their current home in south London, where prices were cheaper and travel time to work for his partner was shorter. Chris was coming to the end of his teaching career and liked the area where he lived, but did not feel that he had been a pioneer of gentrification. He and his partner had practically no links with the local community, either formal or through using the local amenities of clubs, pubs, restaurants and cafés. Chris observed the changes to his local environment with the detachment of an outsider:

I would say that this area was originally a very working class area but there is a huge influx of middle class people coming into the area... it's a friendly area and the people are all quite middle class.

When asked about his future residential plans, Chris was uncertain:

I don't know, I have no great affection for this area as such. I would prefer to live a few miles up the road, which is a very nice part of London...here it's handy for the station if you're commuting.

Like Jean-François in Paris, it was London as a whole that was an important location for Chris, rather than his current locality. Indeed, Chris' identification was such that despite having been born in Yorkshire, he considered himself to be a Londoner:

I have always lived in London and I think when you go and visit these places they are nice to go and visit but I really don't think I would sort of go and live there. 
Within the city movers, the interviews also revealed the existence of residential trajectories that exemplified stereotypes of the 'eternal youth' image that is often associated with the baby boomer generation (Harkin \& Huber 2004). In Paris, these were past activists of the 1968 movement and in London the student scene of the late 1960s. These individuals had often lived in many different locations, sometimes spending many years abroad. Family relationships were complex and several of the individuals with this profile were not living permanently with a partner. The residential trajectories of these individuals, including their current and future locations thus had a 'drift' feel to them, in keeping with their life styles.

\section{Local inhabitants}

The 'local' baby boomer inhabitants were those who either grew up in or very close to their current address. For our London example, we have not chosen a residential trajectory that has been static (mostly local authority renters), but one that reflects how local inhabitants 'compete' with newcomers in residential strategies within gentrified areas. Julie was born in north London in 1953 to working class parents. After leaving school and working as a secretary, she met her future husband in 1976, and together they rented a small flat in the private sector, close to Julie's parents. In 1980, the couple was offered a local authority flat on a council estate, towards the west of the borough where there was little gentrification taking place. In 1987, Julie's husband received some compensation from a workrelated accident, and the couple decided to buy a home to the east of the borough, in an area that was quickly becoming gentrified. In 1999, needing more space for the family but not being able to afford a large enough house in the immediate local area, the couple bought a four bedroom property that needed renovation towards the north of the borough and this was the home she lived in when interviewed in 2006. This area is less gentrified, and Julie had very mixed feelings about her local environment. Ideally, she would have liked to move back to the more gentrified area of the borough where she grew up, but realised that on their budget this was not possible. Julie explains:

Well, we are doing up the house, and I mean, the house is lovely and the neighbours, I know most of them, but the area is really 
dangerous. There are a lot of social cafes and heroin dealing and massage parlours where they are bringing in girls from Eastern Europe...

Julie's case was typical of other London 'local' baby-boomers interviewed who whilst managing to have become home-owners, lagged behind the pioneers and city movers in terms of having achieved their desired choice of location. Whilst local links had been made with neighbours and through activities linked to the schooling of their children, Julie's narrative about her area revealed a certain degree of alienation and discontentment. Still very much engaged in the project of renovating the house, Julie had no immediate plans for moving home, although she felt that some day she would leave the area. Yet she was aware that there was little likelihood of her returning to the area where she grew up or nearby areas that had since become too expensive. Julie's rationale for a future move fitted clearly in the housing disequilibrium category of residential choice, since her future move would be 'to get a better house in an area that was cheaper'. For Julie, and other 'local' interviewees, the quality of the home often took precedent over the quality of the area.

Our Paris example of a local baby-boomer inhabitant is Sylvie, 58 at the time of interview and a bank employee. Sylvie was born in Paris in the same arrondissement as her current home in 2006. She was immensely proud of her 'Parisienne' status, and at numerous points throughout the interview the importance of locality for her sense of identity was clearly demonstrated. The daughter of a carpenter, she grew up in the flat above her father's workshop and lived there until she married in 1975. Encouraged by her father to buy property, she and her husband obtained a lowcost mortgage in 1980 and bought a one-bedroom flat. A few years later and with a second (15 year) mortgage the couple bought a two-bedroom flat which remained their home in 2006. Two of her sons had left home, one married and living about $2 \mathrm{~km}$ away, the other living with his fiancé in the same apartment block as Sylvie, having been helped on the housing ladder by his parents. The couple had no other property other than a country caravan, but as an only son, her husband will inherit his mother's house in the country some $250 \mathrm{~km}$ from Paris. Sylvie had definitively no plans to move home and will stay where she is 'until the end'. 
Both Sylvie and her partner were engaged in voluntary activities with their local neighbourhood and retain a strong attachment to the local area. They had, of course, seen many changes including the gentrification of the area, which they generally considered to be negative. Sylvie expressed a feeling of being 'drowned out' by the influx of middle class newcomers to the area. She talked about bygone times when the neighbourhood was more homogenous and cohesive. The apartment block where she currently lived was a mixture of private and rented property, which according to Sylvie reflected more generally the social divisions of the neighbourhood - the pretensions and snobbishness of the mainly middle class home-owners in contrast to the 'simplicity' of the renters. The transformation of the craftsman (artisan) workshops into high fashion shops and trendy cafés was not at all to Sylvie's taste. Nevertheless, Sylvie had in a sense survived the onslaught of gentrification to her neighbourhood, a process which she believed was nearing completion. She herself had moved through different social strata, from the daughter of a tradesman to a bank employee, reflecting the wider social transformations of the second half of the twentieth century. Generally at ease in her neighbourhood and engaged in local activities, she and her husband represented a commonplace trajectory of 'original' local inhabitants in Paris for whom growing old in the city was not a source of anxiety.

It is not possible to draw any firm conclusions from these two case studies concerning the link between having lived most of one's life in an inner city area and perceptions about the quality of life within inner cities. There are local inhabitants of the baby boomer generation in London, who also remain attached to their neighbourhood in the same way that our Paris case study reported. At the same time, the Parisian local inhabitants seemed in many ways more secure of their place in the city than the London local inhabitants, perhaps because many of them had not been 'overtaken' by the process of gentrification and social change. With generally affordable rents and the prospect of more generous pensions than their London counterparts, the Parisian local inhabitants seem to feel more at ease in their neighbourhoods and less mobile. We cannot be sure that this is a major or even a significant trend, and more work will need to be undertaken with the data to try and establish the complex links 
between residential trajectories, cohorts and residential choices for retirement.

\section{Conclusion}

It has often been observed that the demographic connotation of the baby boom, with its emphasis on numerical strength, is reflected in the social diversity that is found within it. At the same time, the collective experience of belonging to a generation and the specificities of the baby boom generation are frequently portrayed as a being a watershed in wider social transformations. This paradox, of diversity in numbers versus commonalities, lies at the heart of current debates about the importance of the baby boom generation. In the example of residential trajectories and mobility that have been considered in this paper, the tension between similarity and difference is immediately apparent. All of the interviewees that participated in the research shared the common experience of belonging to the same age cohort and living in inner cities. Further commonalities existed in so far as some individuals had moved to the city whilst others were local inhabitants. But from there onwards, the residential trajectories, patterns of mobility and future residential choices displayed a range of diversity that reflected life course events, economic factors, and local and national variation. From this diversity, how far is it possible to establish the competing influences that determine a major life decision such as where to live?

The comparative research undertaken here can serve as a basis for answering this question. Returning to the types of residential trajectories that were developed through the 60 interviews undertaken in London and Paris, tentative conclusions can be drawn concerning possible future trends in residential mobility. The first is that for pioneers of gentrification who are now in mid-life, the city still retains the features that made it attractive in their youth. At the same time, there is a suggestion that the particular neighbourhood does not anchor mid-lifers to their locality and that the pioneers of gentrification are prepared to uproot in the near future. Returning to Longino's model of retirement migration decisions, we found that the London pioneers of gentrification were more likely to articulate their choices in the context of the 'housing disequilibrium model', 
whereas the Paris pioneers of gentrification were more associated with the 'life course model'. These differences we attribute mainly to the economic contexts of the two locations. In Britain, current retirees have a high level of wealth in housing but uncertainties over the capacity of retirement incomes to sustain their quality of life. In France, the relative stability of pension income continues to fuel more long-term retirement decision planning that is a feature of the life course model of retirement migration.

A further influence on residential choices at the time of retirement is the independence of children and the geographical dispersion of family members which tend to act as disincentives to remaining indefinitely at their current address. For London pioneers of gentrification, high housing equity and an anticipated fall in income in retirement are push factors for residential mobility. In both London and Paris, the mid-life pioneers of gentrification are active participants in the 'mobile culture' that encapsulates second homes, extended travel, time-shares, and forms of 'double residence'. 'City movers' - mid-lifers who did not grow up in London or Paris but who are not gentrifiers- also continue to look positively on the prospect of ageing in the city, but like gentrifiers it is the cosmopolitan aspects of city life that take precedence over ties to the local neighbourhood. The retirement migration choices of 'city movers' are less well articulated than the 'pioneers of gentrification', and more in line with Longino's second model, where the desire to move is the main motivation and the location often unclear.

'Local inhabitants' are divided about the transformations to the area, acknowledging general improvements to buildings and the infrastructure but disapproving of changes in the population structure and the loss of a uniform social cohesion. Nevertheless, their attachment to the area remains strong, particularly in Paris, and retirement migration plans, where they do occur, are mainly focussed on extended periods of time spent outside the capital, either in second homes or as part of a more general mobility involving holidays and visits abroad.

Overall, the narratives of ageing mid-lifers suggest that the appeal of the city remains strong. This appeal is in keeping with the metaphor of 'eternal youth' frequently associated with baby boomers. The attractions that the city held in youth do not seem to have diminished dramatically. 
Some baby boomers may be destined to grow old in cities, but the precise nature of future residential trajectories is unknown. For many mid-lifers of the baby boomer generation, the factors that determine residential choices - 'where will the children live?', 'how much household income will there be in retirement?', 'how healthy will I be?', 'what future transformations will occur to the neighbourhood?' - are unknown and rarely fall into place simultaneously. When these factors are positive, inner city baby boomers seem likely to move into old age combining a range of residential strategies. But if they are negative, will the city continue to be a favoured location and more importantly will it respond to the needs of those baby boomers whose residential horizons are limited?

\section{Acknowledgements}

The authors would like to thank Belinda Brown and Olivia Lelong for their help in interviewing and subsequent discussions, Sylvie Renaut and the anonymous referee for helpful comments on earlier drafts, as well as the interviewees who took part in the research.

\section{References}

Bonnin, P. \& Villanova, R. (eds.) (1999). D'une maison l'autre. Paris: Créaphis.

Bonvalet, C. (2007). Vieillissement de la population et logement: les stratégies résidentielles et patrimoniales. In C. Bonvalet, F. Drosso, F. Benguigui \& M. Huynh (eds.), Vieillissement de la population et logement. Les stratégies résidentielles et patrimoniales. Paris: La Documentation Française.

Bonvalet, C. \& Merlin, P. (eds.) (1988). Les transformations de la famille. Paris: La Documentation Française.

Bonvalet, C., Gotman, A. \& Grafmeyer, Y. (eds.) (2007). Family Kinship and Place in France. London: Southern Universities Press.

Butler, T. (1997). Gentrification and the Middle Classes. Aldershot: Ashgate.

Butler, T. (2006). Gentrification and Globalization: the emergence of a middle range theory? 
http://www.portedeurope.org/IMG/pdf/cahier_ville014.pdf $\quad$ (Last accessed November 18, 2007).

Butler, T. \& Robson, G. (2001). 'Social capital, gentrification and neighbourhood change in London: a comparison of three south London neighbourhoods'. Urban Studies 38(12): 2145-2162.

Butler, T. \& Robson, G. (2003). London Calling: the Middle Classes and the Remaking of Inner London. Oxford: Berg.

Champion, T. (2005). Migration and British Cities. London: The Treasury. http://eprints.ncl.ac.uk/file_store/nclep_421141728076.pdf.

Christel, V. (2006). Trajectoires résidentielles des personnes âgées. Données sociales - La société française. Paris : INSEE.

Clark, E. (2005). The order and simplicity of gentrification - a political challenge. In R. Atkinson \& G. Bridge, Gentrification in a Global Context: the New Urban Colonialism. London: Routledge.

Cribier, F. (1988). Le logement à l'heure de la retraite: l'exemple des Parisiens. In C. Bonvalet \& P. Merlin (eds.), Transformation de la Famille et Habitat, INED, DREIF, IDEF, Travaux et Documents, 120, Paris.

Dench, G., Gavron, K. \& Young, M. (2006). The New East End: Kinship, Race and Conflict. London: Profile Books.

Ermisch, J. F. \& Jenkins, S. P. (1999). Retirement and housing adjustment in later life: evidence from the British Household Panel Survey. Labour Economics, 6(2): 311-333.

Glass, R. (1964). London: Aspects of Change. Centre for Urban Studies. London: MacGibbon \& Kee.

Gotman, A. (1989). Familles, générations, patrimoine : une question urbaine. In Les annales de la Recherche Urbaine, 41.

Hamnett, C. (2003). Gentrification and the middle class remaking of inner London, 1961-2001. Urban Studies 40(12): 2401-26.

Harkin, J. \& Huber, J. (2004). Eternal Youths: How the Baby Boomers are having their Time Again. London: Demos.

Lelièvre, E. \& Bonvalet, C. (1994). A compared cohort history of residential mobility, social change, and home-ownership in Paris and the rest of France, Urban Studies 31: 1647-1665.

Ley, D. (1996). The New Middle Class and the Remaking of the Central City. Oxford: Oxford University Press. 
Loiseau, M. \& Bonvalet, C. (2005). The impact of the 1948 housing law on residential trajectories in the Paris region. Population-E 60(3): 301-316.

Longino Jr., C.F. (2001). Geographical distribution and migration. In R. Binstock \& L. George (eds.), Handbook on Aging and the Social Sciences, 5th Edition. New York: Academic Press.

Louchart, P. (2007). Où vieilliront les générations du baby-boom? In C. Bonvalet, F. Drosso, F. Benguigui \& M. Huynh (eds.), Vieillissement de la population et logement. Les stratégies résidentielles et patrimoniales. Paris: La Documentation Française.

Phillipson, C. (2007). The 'elected' and the 'excluded': sociological perspectives on the experience of place and community in old age. Ageing and Society 27(3): 321-342.

Phillipson, C., Bernard, M., Phillips, J. \& Ogg, J. (2001). The Family and Community Life of Older People: Social Networks and Social Support in Three Urban Areas. London: Routledge.

Pinçon, M. \& Pinçon-Charlot, M. (2004). Sociologie de Paris. Paris, La Découverte.

Rothenberg Pack, J. (1973). Determinants of migration to central cities. Journal of Regional Science 13(2): 249-260.

Savage, M., Bagnall, G., \& Longhurst, B. (2005). Globalization and Belonging. London: Sage.

Scharf, T., Phillipson, C., Kingston, P. \& Smith, A.E. (2001). Social exclusion and older people: exploring the connections. Education and Ageing 163: 303-320.

Smith, N. (1996). The New Urban Frontier: Gentrification and the Revanchist City. London: Routledge.

Tatsiramos, K. (2006). Residential mobility and the Housing adjustment of the elderly in Europe. IZA Discussion Paper, no. 2435.

Urry, J. (2001). Sociology beyond Societies: Mobilities for the 21st Century. London: Routledge.

Warnes, A.M. (1992). Migration and the life course. In T. Champion \& T. Fielding (eds.), Migration Processes and Patterns. London: Belhaven Press. 
International Journal of Ageing and Later Life

Warnes, T. (2007). Migrants âgés en Europe: parcours et statuts sociaux multiples. In C. Bonvalet, F. Drosso, F. Benguigui \& M. Huynh (eds.) Vieillissement de la population et logement. Les stratégies résidentielles et patrimoniales. Paris: La Documentation Française, Paris.

Wiseman, R.F. (1980). Why older people move. Research on Aging 2(2): 141154. 